\section{Climatic influence on conjunctival bacteria of patients undergoing cataract surgery}

Ophthalmic Institute

Laboratory

Department of

Ophthalmology

'Gregorio Marañon'

University General Hospital

Madrid, Spain

Correspondence: EF Rubio cNizconde de los Asilos

12, 2 B 28027 Madrid

Spain

Tel: + 34915867326

Fax: + 34917423586

E-mail: elfernan@

wol.es

Received: 23 April 2003

Accepted in revised form:

25 November 2003

Published online: 27

February 2004

\begin{abstract}
Purpose To describe the monthly prevalence of conjunctival bacteria in patients undergoing cataract extraction and the possible climatic influence on it, in Madrid, in order to clarify postsurgical endophthalmitis pathogenesis.

Methods The lower conjunctival content sample of 4432 consecutive patients awaiting cataract surgery was cultured from January 1994 to December 1996. The dates of the operations and the rehospitalization for postsurgical endophthalmitis, if this took place, were checked. The isolated bacteria were grouped to study the statistical significance of the differences in the monthly prevalence differences ( $\chi^{2}$ tests). Temperature and relative humidity are given monthly for the area where our patients live.

Results The total frequency of the conjunctival bacteria increases in April, May, and June, when the daily average temperature rises from 12 to $22^{\circ} \mathrm{C}$ and the relative humidity oscillates between 45 and $60 \%$ in our area. Bacteria groups' frequency was significantly higher as follows: Staphylococci coagulase negative ( $>60 \%$ ) in April, May, and June; Corynebacterium sp ( $>33 \%$ ), Staphylococcus Aureus ( $>8 \%$ ), and other Gram-positive bacteria ( $>2.5 \%$ ) in May; Streptococcus Pneumoniae increases $(>3.4 \%)$ in March, November, and December; Haemophilus sp ( $>3.4 \%$ ) in January and April; Gram-negative Cocci ( $>3 \%$ ) in April; and other Streptococcus sp ( $>6 \%)$ in April, May, and September. Our incidence of rehospitalization for endophthalmitis after cataract extraction in May and June together was 3.37 times higher than in the other months.

Conclusion Conjunctival bacteria of our patients undergoing cataract surgery present a
\end{abstract}

EF Rubio

seasonal prevalence pattern, which could be considered as a predisposing condition for having postsurgical endophthalmitis in certain months.

Eye (2004) 18, 778-784. doi:10.1038/sj.eye.6701352

Published online 27 February 2004

Keywords: conjunctival bacteria; cataract surgery; climatic factors; postsurgical endophthalmitis

\section{Introduction}

In a recent study in Switzerland, an increased incidence of postsurgical endophthalmitis (PE) after cataract extraction in April, May, and June was attributed to climatic factors. ${ }^{1}$ Also in the same period, in Scotland, ${ }^{2}$ a hospital infection control team reported more acute PE than expected after cataract surgery, according to the normal incidence. ${ }^{3}$

Among the many risk factors involved in the PE pathogenesis, ${ }^{4-11}$ it is difficult to assess the weight of climatic influence; however, as conjunctival bacteria are the main source of contamination in cataract surgery, ${ }^{12,13}$ it is quite logical to expect that the prevalence of conjunctival bacteria determines the prevalence of the infectious PE. Today, the world-wide use of povidona iodine solution as a preoperative prophylaxis in cataract extraction ${ }^{14}$ could provide homogeneity in the kind of bacteria that produce PE all over the world, which was impossible to detect when a great number of different prophylactic techniques were used. ${ }^{15,16}$

On the other hand, it is well known that climatic factors determine the incidence of conjunctivitis over the year in many parts of the world; ${ }^{17}$ it is worth mentioning the study of the seasonal pattern of conjunctivitis in London, ${ }^{18}$ which describes the responsible bacteria month 
by month. These data suggest the possibility of some patients undergoing cataract surgery being affected spontaneously by conjunctivitis due to climatic influence.

Herein, the monthly prevalence of conjunctival bacteria in a large sample of patients awaiting cataract surgery is studied, in order to consider if climatic influence would be another risk factor for having infectious PE after such operations, which could help to understand the pathogenesis of this serious infection, and perhaps to improve its prevention.

\section{Materials and methods}

\section{Study design}

A retrospective prevalence study was performed using the routine preoperative conjunctival culture of every patient awaiting cataract extraction in the Ophthalmic Institute of the Gregorio Marañon University General Hospital, in Madrid. The preoperative conjunctival bacteria of 4432 consecutive patients, cultured from January 1994 to December 1996, has been recorded in a database DB3 Plus (one record per patient) in Ophthalmic Institute Laboratory.

At least a year after the cataract extraction, it has been confirmed by means of the hospital-computerized codes for diagnoses and surgical procedures from the International Classification of Diseases: Ninth revision ${ }^{19}$ that every patient from our laboratory database had been operated on, and the date of the surgery had been recorded; at the same time, the date of the rehospitalization for PE was recorded if it took place. Every medical record of a patient rehospitalized for PE was examined, retrospectively, to check, among other things, if the affected eye was that operated on for cataract extraction. No patients had been excluded from the planned surgery for any pre-existing conditions and all of them were advised not to use any antibiotic eye drops during the $48 \mathrm{~h}$ before taking the conjunctival sample, and not to wash the eyes that day, before taking the sample in the early morning. The age of the patients ranged from 3 to 97 , the average being $71 \pm 11$ and $53 \%$ of them being women.

The climatic characteristics of the 3-year study period were obtained from the Spanish National Institute of Meteorology, by means of an official request. The data correspond to the Retiro Station, the nearest meteorological station to where our patients live, next to our Hospital. The two climatic variables, temperature and relative humidity, have been chosen because of being statistically associated with the monthly conjunctivitis incidence in Madrid. ${ }^{20}$ It is collected in addition to the monthly average of the same data in the period 1971-2000 published by the National Institute of
Meteorology in a guide, ${ }^{21}$ in this guide ${ }^{21}$ other meteorological data are available, in case Ophthalmologists elsewhere would like to compare the climatic characteristics of their areas.

\section{Microbiological method}

The technique used to obtain the conjunctival flora consists of taking a sample of the content of the lower conjunctiva sac with a microlitre platinum loop and spreading it on each of the three culture media used (blood-Agar, chocolate-Agar supplemented with polivitex and MacConkey-Agar). We use one plate for each patient, with an eye sample on each half-plate. The media were incubated for $48 \mathrm{~h}$; to the chocolate-Agar $10 \%$ of $\mathrm{CO}_{2}$ was added. The identification of the isolated bacteria was made following the procedures described in the Manual of Clinical Microbiology. ${ }^{22}$

The isolated bacteria were grouped into nine categories, two of nonpathogen flora (Staphylococci coagulase negative and Corynebacterium sp), and seven of pathogen flora (Staphylococcus Aureus, Streptococcus Pneumoniae, other Streptococcus sp, Haemophilus sp, other Gram-negative rods, Gram-negative cocci, and other Gram-positive bacteria). The bacteria of all nine categories were tabulated, grouping together the same month for each of the 3 years, in order to obtain enough quantities of the scarce bacteria to allow statistical calculations.

\section{Statistical study}

The estimation of the total percentage of every bacteria group over the 3-year period was possible, in spite of obtaining very low bacteria percentages for some of the groups, because of having a large sample of patients. Percentages of the conjunctival bacteria isolated month by month are represented in Figures 1-3, using Microsoft Excel 97, separated according to the typical site where they could come from.

The statistical significance of the differences between the conjunctival bacteria prevalence in different months was studied by means of the $\chi^{2}$ test, using Microsoft Excel 97; the monthly differences of those bacteria groups having high percentages (Staphylococcus coagulase negative and Corynebacterium $\mathrm{sp}$ ) were studied for the 11 months with 10 freedom degrees (fd). The monthly frequencies of the pathogen bacteria group (quite low) were considered to be different when they rose to a percentage much higher than the upper limit of the confidence interval (CI) of the total percentage of every bacteria group, and the frequencies of some months were grouped into two categories, following this criterion, to calculate the correspondent $\chi^{2}$ test with one $\mathrm{fd}$. 


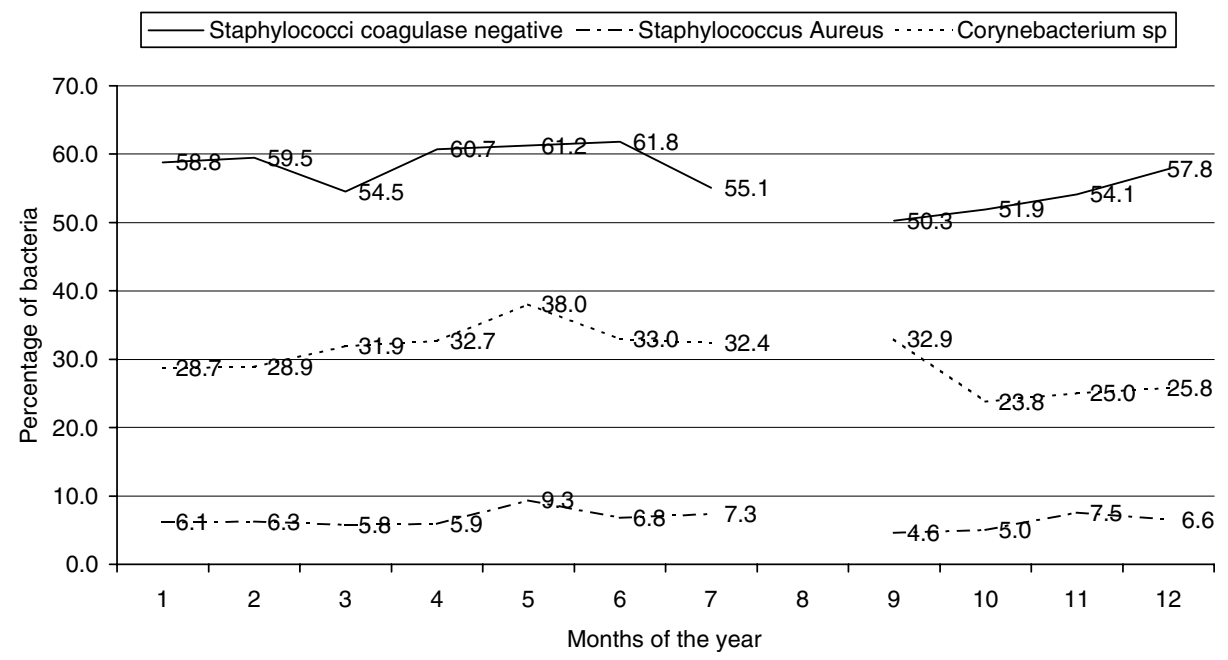

Figure 1 Monthly percentage of typical skin bacteria on the conjunctiva.

\begin{tabular}{|ll|}
\hline- Streptoccus Pneumoniae & --- Other Streptococcus \\
…- Haemophilus sp. & --- Gram negative Cocci \\
\hline
\end{tabular}

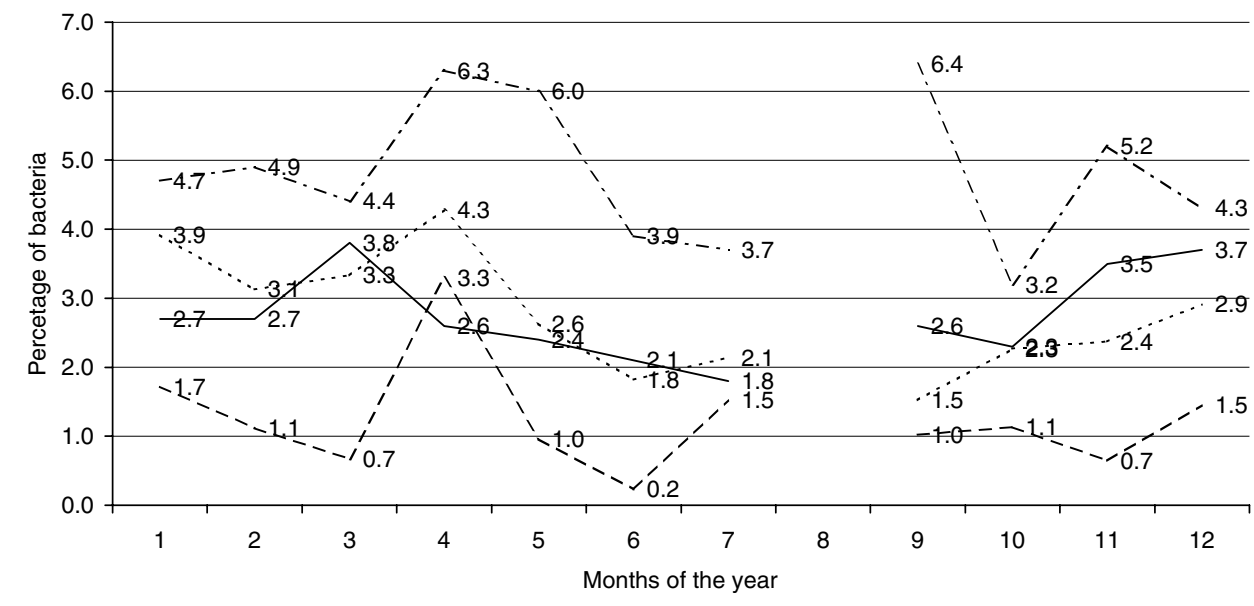

Figure 2 Monthly percentage of bacteria typical of the respiratory system on the conjunctiva.

\section{Results}

The number of analysed patients and the monthly frequency of every bacteria group are summarized in Table 1, except for the month of August, which has been removed from the study because the total number of cultures in the 3 years was less than a hundred and it was considered that those bacteria whose frequency was less than $1 \%$ could either be missed or overestimated..$^{23}$ More than one bacterium was isolated in some patients' conjunctiva, the total percentage of the isolated bacteria being higher than $100 \%$ in most of the months.

The percentage estimation of the conjunctival bacteria isolated in the 11 months considered is shown in Table 2 .
The whole bacteria percentage increases in April, May, and June quite much; over the total months ${ }^{7}$ frequency (109.50\%); the total percentage of pathogen bacteria increases over the upper CI limit of the total months' frequency $(24,20 \%)$ in April, May, November, and December (Table 1).

Among the monthly percentage of each of the nine bacteria groups represented in Figures 1-3, the increase of typical skin bacteria in May, and most bacteria typical of the respiratory system in April is very clear.

The statistical significance of the differences between the monthly frequency for every bacteria group is described in Table 3. The $\chi^{2}$ tests for Staphylococcus coagulase negative and Corynebacterium sp groups turned 


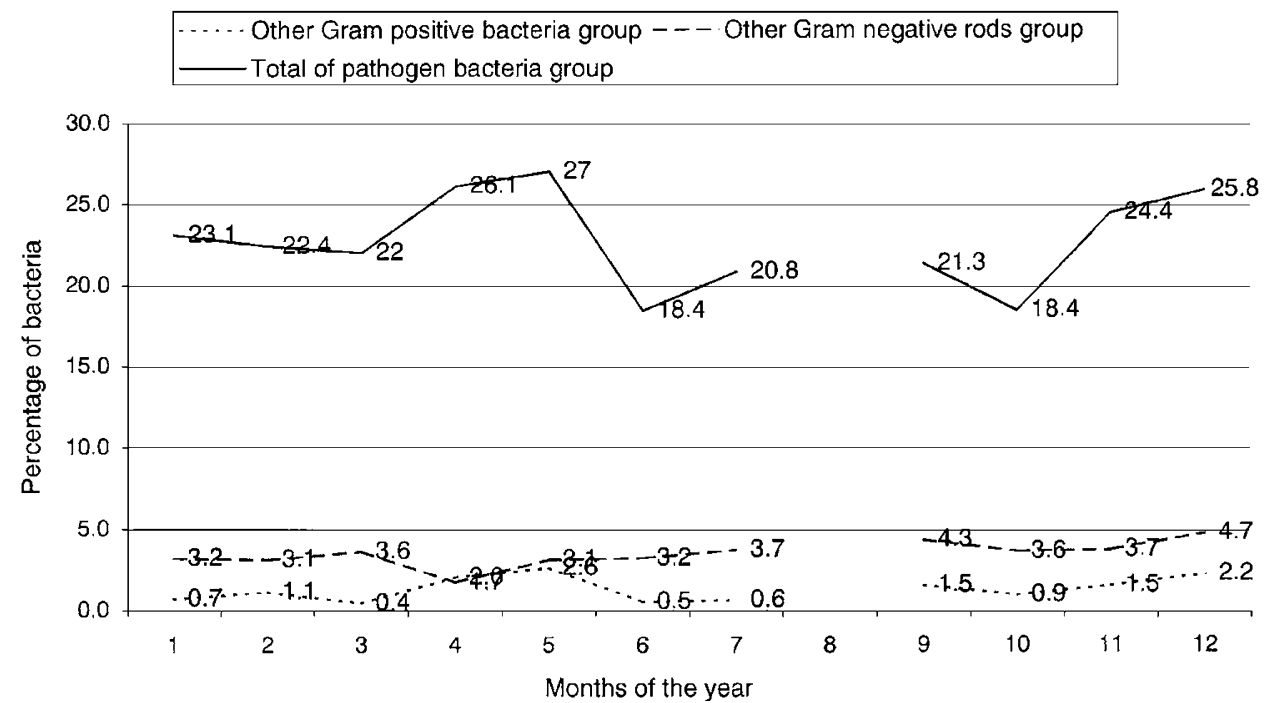

Figure 3 Monthly percentage of bacteria from other sources on the conjunctiva.

Table 1 Monthly frequency of grouped conjunctival bacteria in patients awaiting cataract surgery

\begin{tabular}{|c|c|c|c|c|c|c|c|c|c|c|c|c|}
\hline Months & January & February & March & April & May & June & July & September & October & November & December & Total \\
\hline Number of patients & 408 & 447 & 451 & 303 & 418 & 440 & 327 & 392 & 441 & 464 & 275 & 4366 \\
\hline Staphylococci coagulase(-) & 240 & 266 & 246 & 184 & 256 & 272 & 180 & 197 & 229 & 251 & 159 & 2480 \\
\hline Corynebacterium sp & 117 & 129 & 144 & 99 & 159 & 145 & 106 & 129 & 105 & 116 & 71 & 1320 \\
\hline Staphylococcus Aureus & 25 & 28 & 26 & 18 & 39 & 30 & 24 & 18 & 22 & 35 & 18 & 283 \\
\hline Streptococcus Pneumoniae & 11 & 12 & 17 & 8 & 10 & 9 & 6 & 10 & 10 & 16 & 9 & 118 \\
\hline Other Streptococcus sp & 19 & 22 & 20 & 19 & 25 & 17 & 12 & 25 & 14 & 24 & 13 & 210 \\
\hline Haemophilus sp & 16 & 14 & 15 & 13 & 11 & 8 & 7 & 6 & 10 & 11 & 8 & 119 \\
\hline Gram-negative cocci & 7 & 5 & 3 & 10 & 4 & 1 & 5 & 4 & 5 & 3 & 4 & 51 \\
\hline Other Gram-negative rods & 13 & 14 & 16 & 5 & 13 & 14 & 12 & 17 & 16 & 17 & 13 & 150 \\
\hline Other bacteria & 3 & 5 & 2 & 6 & 11 & 2 & 2 & 6 & 4 & 7 & 6 & 54 \\
\hline Total isolated & 451 & 495 & 485 & 362 & 528 & 498 & 354 & 412 & 415 & 480 & 301 & 4781 \\
\hline$\%$ of total isolated & 110.5 & 110.7 & 107.5 & 119.5 & 126.3 & 113.2 & 108.3 & 105.1 & 94.1 & 103.4 & 109.5 & 109.5 \\
\hline Total pathogen & 94 & 100 & 99 & 79 & 113 & 81 & 68 & 86 & 81 & 113 & 71 & 985 \\
\hline$\%$ of total pathogens & 23.0 & 22.4 & 22.0 & 26.1 & 27.0 & 18.4 & 20.8 & 21.3 & 18.4 & 24.4 & 25.8 & 22.6 \\
\hline
\end{tabular}

Table 2 Statistical estimation of the percentages of preoperative conjunctival bacteria in 4366 patients awaiting cataract surgery in the eleven months considered

\begin{tabular}{lrrr}
\hline Bacteria group & $\mathrm{N}$ & $(\%)$ & CI limits $($, ) \\
\hline Staphylococcus coagulase (-) & 2480 & 56.80 & $(54.85 \%, 58.75 \%)$ \\
Corynebacterium sp & 1320 & 30.20 & $(28.39 \%, 32.01 \%)$ \\
Staphylococcus Aureus & 283 & 6.40 & $(5.44 \%, 7.36 \%)$ \\
Streptococcus Pneumoniae & 118 & 2.70 & $(2.06 \%, 3.34 \%)$ \\
Other Streptococcus sp & 210 & 4.81 & $(3.97 \%, 5.65 \%)$ \\
Haemophilus sp & 119 & 2.73 & $(2.09 \%, 3.37 \%)$ \\
Other Gram (-) rods & 150 & 3.44 & $(2.72 \%, 4.16 \%)$ \\
Gram (-) Cocci & 51 & 1.17 & $(0.75 \%, 1.59 \%)$ \\
Other Gram (+) bacteria & 54 & 1.24 & $(0.80 \%, 1.68 \%)$ \\
Total pathogen bacteria & 985 & 22.56 & $(20.09 \%, 24.20 \%)$ \\
\hline
\end{tabular}

Confidence interval limits, $P<0.01$. 
Table 3 Statistical significance of the monthly frequency differences in conjunctiva bacteria of 4366 patients awaiting cataract surgery over eleven months

\begin{tabular}{lcrr}
\hline Isolated bacteria & Two Monthly frequency categories & $\chi^{2}$ & $P$-values \\
\hline Staphylococcus coagulase (-) & $>60.0 \%$ and $<60.0 \%$ & 13.19 & 0.0003 \\
Corynebacterium sp & $>33.0 \%$ and $<33.0 \%$ & 13.35 & 0.0003 \\
Staphylococcus Aureus & $>8.0 \%$ and $<8.0 \%$ & 6.19 & 0.0129 \\
Streptococcus Pneumoniae & $>3.3 \%$ and $<3.3 \%$ & 4.25 & 0.0392 \\
Other Streptococcus sp & $>5.7 \%$ and $<5.7 \%$ & 6.30 & 0.0121 \\
Haemophilus sp & $>3.4 \%$ and $<3.4 \%$ & 4.79 & 0.0162 \\
Other Gram-negative rods & $>4.2 \%$ and $<4.2 \%$ & 1.89 & 0.1697 \\
Gram-negative cocci & $>3.0 \%$ and $<3.0 \%$ & 12.82 & 0.003 \\
Other Gram-positive bacteria & $>2.5 \%$ and $<2.5 \%$ & 7.36 & 0.0067 \\
Total pathogen bacteria & $>24.2 \%$ and $<24.2 \%$ & 7.86 & 0.0051 \\
\hline
\end{tabular}

Table 4 Climatic data in the area where our patients live

\begin{tabular}{|c|c|c|c|c|c|c|c|c|}
\hline & \multicolumn{4}{|c|}{ Monthly average humidity (\%) } & \multicolumn{4}{|c|}{ Monthly average temperature $\left({ }^{\circ} \mathrm{C}\right)$} \\
\hline & 1994 & 1995 & 1996 & $1971-2000^{c}$ & 1994 & 1995 & 1996 & $1971-2000^{\circ}$ \\
\hline January & 70 & 72 & 81 & 71 & 6.1 & 6.8 & 7.9 & 6.1 \\
\hline February & 70 & 72 & 64 & 65 & 7.1 & 8.9 & 6.4 & 7.9 \\
\hline March & 57 & 52 & 61 & 54 & 13.9 & 11.5 & 10.2 & 10.7 \\
\hline April & 54 & 48 & 56 & 55 & 12.1 & 14.5 & 14.0 & 12.3 \\
\hline May & 61 & 48 & 61 & 54 & 16.8 & 18.9 & 15.8 & 16.1 \\
\hline June & 45 & 47 & 45 & 46 & 22.7 & 22.0 & 22.8 & 21.0 \\
\hline July & 41 & 39 & 41 & 39 & 27.8 & 26.4 & 25.0 & 24.8 \\
\hline August & 48 & 44 & 46 & 41 & 24.6 & 25.1 & 23.6 & 24.4 \\
\hline September & 59 & 53 & 56 & 50 & 18.6 & 18.3 & 18.3 & 20.5 \\
\hline October & 72 & 61 & 65 & 64 & 15.4 & 17.5 & 15.0 & 14.6 \\
\hline November & 78 & 78 & 70 & 70 & 11.3 & 11.7 & 10.2 & 9.7 \\
\hline December & 79 & 86 & 83 & 74 & 7.2 & 8.3 & 7.4 & 7.0 \\
\hline
\end{tabular}

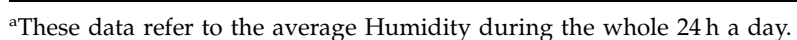

${ }^{\mathrm{b}}$ These data refer to the average Temperature during the whole $24 \mathrm{~h}$ a day.

'These data are the mean of the monthly average during these years.

out to be significant $(P<0.01)$, May, June, and July being the months when frequencies increased. The results for other bacteria groups, studied for one $\mathrm{fd}$, were as follows: the Staphylococcus Aureus frequency in May (>8\%) was statistically different from that of the other months $(P=0.013)$; the Streptococcus Pneumoniae frequency in March, November and December $(>3.4 \%)$ was significantly higher than in the other months $(P=0.04)$; the other Streptococcus $s p$. frequency increases significantly $(P=0.012)$ in April, May, and September ( $>6 \%)$; Haemophilus sp increases significantly $(P=0.016)$ in January and April ( $>3.4 \%)$; Gram-negative Cocci increase significantly $(P<0.001)$ in April $(>3 \%)$; and other Gram-positive bacteria increase significantly $(P=0.007)$ in May $(>2.5 \%)$.

In Table 4 , the monthly average relative humidity (\%) and temperature in degrees centigrade $\left({ }^{\circ} \mathrm{C}\right)$ over the study period are given, as well as the mean of the monthly average of the same data for the period 1971-
2000, in the area where our patients live. As the relative humidity in March, April, and May are quite similar, the increased conjunctival bacteria frequency over these months would more likely depend on temperature; for instance, we have found that all Gram-positive bacteria (except most Streptococcus sp) increased between 15 and $19^{\circ} \mathrm{C}$ in May; most bacteria typical of the respiratory system increased between 9 and $15^{\circ} \mathrm{C}$ in March, April, and November, except part of the Haemophilus sp which also increased under $9^{\circ} \mathrm{C}$ in January and February, and some Streptococcus sp (different from Streptococcus Pneumoniae), which also increased over $15^{\circ} \mathrm{C}$ in May and September.

Among the 4432 patients analysed in the 3-year study period, 851 were operated on during May and June. The operation took place more than a week after the preoperative culture. Therefore, the 851 patients operated on in May and June did not correspond exactly to the 858 preoperative conjunctival cultures processed in the same 
months. The incidence of rehospitalization for infectious PE of those patients operated on in May and June turned out to be 3.37 times higher than the incidence in the other 3581 patients operated on in other months.

\section{Discussion}

The influence of climatic factors on the monthly conjunctival bacteria prevalence of patients undergoing cataract surgery has been demonstrated in our area. In April, May, and June, the total frequency of conjunctival bacteria was surprisingly higher than in the other months (Tables 1 and 2); a large part of this increase was due to the normal flora that represent the most frequent ocular bacteria; however, the higher percentages of pathogen bacteria were found in April and May (Table 1), May being the month where most normal and pathogen bacteria were found on the conjunctiva. We did not find similar studies to compare our data with. Therefore, prospective studies involving more patients in every month would be useful to improve the statistical power.

To know if bacteria prevalence on the conjunctiva determines the prevalence of the infectious PE, it would be necessary to have operated on the patients on the same day such that their conjunctival content was cultured; this did not happen in our hospital, and therefore, it is impossible to demonstrate this association precisely. Moreover, among our infectious PE cases, in the study period, other coexisting risk factors such as patients suffering from diabetes, respiratory disease, pseudoexfoliation syndrome, and those having a secondary intraocular lens implant or other surgical complications, introduce a lot of statistical confusion, which cannot be clarified for some reasons. Firstly, we do not know the frequency of these coexisting risk factors in the whole sample of patients; secondly, even if we had had this information, the sample of infectious PE was too small to perform a statistical study with so many risk factors.

Nevertheless, we know that the incidence of rehospitalization for infectious PE after cataract extraction in May and June was 3.37 times higher than that observed in the other months of the year all together. These data agree with the increased infectious PE observed in Switzerland ${ }^{1}$ and West Scotland ${ }^{2}$ in the same months some years later. This agreement justifies the need for considering climatic factors as a predisposing condition to increase infectious PE incidence in a particular month, when future prospective studies are designed in order to determine the role of the different risk factors in the pathogenesis of this infection.

If we consider the spectrum of bacteria isolated in large series of infectious PE, Gram-positive bacteria were isolated in up to $80 \%$ of the cultures of PE samples after cataract extraction, ${ }^{24,25}$ while about $10 \%$ of Gramnegative bacteria were identified; among Gram-positives, Staphylococci coagulase negative were the most frequently isolated, followed by Staphylococcus Aureus. Both kinds of bacteria present a similar proportion in preoperative conjunctival cultures; ${ }^{23,26,27}$ both increase their prevalence in May and June in our area (Figure 1); and both are typical colonizers of the skin. When these bacteria are responsible for conjunctivitis, they are isolated in the same months at a high level too. ${ }^{17}$

In contrast, infectious PE due to bacteria typical of the respiratory system presents a more variable behaviour, and perhaps the presence of these bacteria on the conjunctiva is related to infections in respiratory diseases. For instance, in the mentioned study from West Scotland, ${ }^{2}$ suffering from a respiratory disease turns out to be a risk factor for having PE after cataract surgery, but this was not described in other PE series studies.

The prevalence of these bacteria over the year, in our patients (Figure 2), and the pattern of conjunctivitis in London, ${ }^{18}$ which present an increase of the typical bacteria of the respiratory system in early spring and autumn, give the impression that respiratory bacteria appear and disappear on the conjunctiva in different months. This behaviour would explain why filtering blebs are associated with endophthalmitis due to Streptococcus sp. and Haemophilus sp and why this endophthalmitis occurs suddenly after there being no sign of infection for months since the last surgery. ${ }^{28}$ For instance, in a series of late-onset endophthalmitis associated with filtering blebs, in the Bascom Palmer Eye Institute, ${ }^{29}$ Streptococci were isolated in $57 \%$ of the cases and Haemophilus influenzae in $23 \%$, and only two cases, from the $83 \%$ positive cultures, were due to

Staphylococci.

No seasonal pattern was demonstrated for the group of Gram-negative rods (different from Haemophilus sp) in our sample (Figure 3), although they show a tendency to increase in the second part of the year; however, in a previous epidemiological study performed in our hospital, where preoperative conjunctival cultures were obtained in August, these Gram-negative rods increase statistically in the summer (panel communication to the Ophthalmology Spanish Society Congress in Sevilla, 1992). These Gram-negative rods, in spite of being responsible for only $6.5 \%$ of the intraocular specimens cultured in the largest case series of endophthalmitis presented 6 weeks after cataract extraction, ${ }^{24}$ are those in which infection progresses quicker. ${ }^{30}$

Summarizing, all these data suggest that the monthly prevalence of the conjunctival bacteria in patients undergoing cataract extraction could predetermine the monthly incidence of infectious PE. In May and June, most conjunctival bacteria are Staphylococci, while 
bacteria typical of the respiratory system would be frequent in the early spring and autumn.

\section{Acknowledgements}

I thank Carlos Cortés, PhD, MD, Head of the Department of Ophthalmology, for providing help with organization needed to obtain a large number of consecutive patients; the entire ophthalmic surgical staff of the department for accepting and following the protocol designed to obtain the conjunctival samples; Teresa Cuesta, MD, for extensive search for PE cases; Rennie IG Professor, Editor of Eye, for providing an old reference; Isabel García for providing the medical records and helping with the code diseases system; and Ana Almazán for microbiological help.

\section{References}

1 Titzé P, Othenin-Girard P, Bernasconi O, Bornet C, GuexCrosier Y. Étude sur les panophtalmies après chirurgie de la cataracte de 1997 à 1999. Klin Monatsbl Augenheilkd 2000; 206: $265-267$.

2 Allardice GM, Wright EM, Peterson M, Miller JM. A statistical approach to an outbreak of endophthalmitis following cataract surgery at a hospital in the West of Scotland. J Hospital Infect 2001; 49: 23-29.

3 Javitt JC, Vitale S, Canner JK, Street DA, Krakauer H, McBean AM et al. National outcomes of cataract extraction. Arch Ophthalmol 1991; 109: 1085-1989.

4 Shrader SK, Band JD, Lauter CB, Murphy P. The clinical spectrum of endophthalmitis: Incidence, predisposing factors, and features influencing outcome. J Infect Dis 1990; 162: $115-120$.

5 Kattan HM, Flynn HW, Pflugfelder SC, Robertson C, Forster RK. Nosocomial endophthalmitis survey. Ophthalmology 1991; 98: 227-238.

6 Menikoff JA, Speaker MG, Marmor M, Raskin EM. A case-control study of risk factors for postoperative endophthalmitis. Ophthalmology 1991; 98: 1761-1768.

7 Maxwell DP, Diamond JG, May DR. Surgical wound defects associated with endophthalmitis. Ophthalmic Surg 1994; 25: 157-161.

8 Chitkara DK, Smerdon DL. Risk factors, complications, and results in extracapsular cataract extraction. J Cataract Refract Surg 1997; 23: 570-574.

9 Montan G, Koranyi G, Setterquist HE, Stridh A, Philipson BT, Wiklund K. Endophthalmitis after cataract surgery: Risk factors relating to technique and events of the operation and patients history. Ophthalmology 1998; 105: 2171-2177.

10 Norregaard JC, Thoning H, Bernth-Petersen P, Andersen TS, Javvitt JC, Anderson GF. Risk of endophthalmitis after cataract extraction: results from the international cataract surgery outcomes study. Br J Ophthalmol 1997; 81: 102-106.

11 McKellar MJ, Elder MJ. The early complications of cataract surgery. Ophthalmology 2001; 108: 930-935.
12 Sherwood DR, Rich WJ, Jacob JS, Hart RJ, Fairchild YL. Bacterial contamination of intraocular and extraocular fluids during extracapsular cataract extraction. Eye 1989; 3: 308-312.

13 Speaker MG, Milch FA, Shah MK, Eisner W, Kreiswirth BN. Role of external bacterial flora in the pathogenesis of acute postoperative endophthalmitis. Ophthalmology 1991; 98: 639-649.

14 Ciulla TA, Starr MB, Masket S. Bacterial endophthalmitis prophylaxis for cataract surgery. Ophthalmology 2002; 109: 13-26.

15 Starr MB, Lally JM. Antimicrobial prophylaxis for ophthalmic surgery. Surv Ophthalmol 1995; 39: 485-501.

16 Mary JC, Salvanet-Bouccara A, Forestier F, Brassseur G. Résultats d'une enquête nationale concernant l'antibioprophylaxie et l'antisepsie dans la chirurgie de la cataracte. J Fr Ophtalmol 1998; 21: 627-635.

17 Duke-Elder S. System of Ophthalmology, Diseases of the Outer Eye. Part I, Vol. VIII. Henri Kimpton (ed) London, 1965, pp 141-152.

18 Jones BR, Andrews BE, Henderson WG, Schofield PB. The pattern of conjunctivitis at Moorfields during 1956. Trans Ophthal Soc UK 1957; 77: 291-305.

19 The International Classification of Diseases. Clinical Modifications, 9th revision, ICD-9CM 3rd edn. Washinton DC: US Department Health Human Services, 1989.

20 Puertas D, Ortiz JM, Ricoy JR. Influencias de algunos parámetros metereológicos en la conjuntivitis. Arch Soc Esp Oftal 1986; 50: 73-78.

21 Guía resumida del clima en España 1971-2000. Plan Estadístico Nacional 2001-2004, Instituto Nacional de Meteorología, Ministerio de Medio Ambiente, Spain, 2001.

22 Lennette EH, Balows A, Hausler WJ, Truant JP Manual de Microbiología Clínica, Sociedad Americana de Microbiología, 3rd ed. Editorial Médica Panamericana: Buenos Aires, 1982.

23 Liotet $\mathrm{S}$. La flore microbienne conjonctivale préopératoire et sa sensibilité aux antibiotiques. J Fr Ophtalmol 1979; 2: $449-458$.

24 Salvanet-Bouccara A, Forestier F, Coscas G, Adenis JP, Denis F. Endophtalmies bactériennes. Résultats ophtalmologiques d'une enquête prospective multicentrique nationale. J Fr Ophtalmol 1992; 15: 669-678.

25 Han DP, Wisniewski SR, Wilson LA, Barza M, Vine AK, Doft $\mathrm{BH}$ et al. Spectrum and susceptibilities of microbiologic isolated in the Endophthalmitis Vitrectomy Study. Am J Ophthalmol 1996; 122: 1-17.

26 Smith $\mathrm{CH}$. Bacteriology of the healthy conjunctiva. $\mathrm{Br} \mathrm{J}$ Ophthalmol 1954; 38: 719-726.

27 Walker CB, Claou CMP. Incidence of conjunctival colonization by bacteria capable of causing postoperative endophthalmitis. J Roy Soc Med 1986; 79: 520-521.

28 Sunaric-Mégevand G, Pournaras CJ. Current approach to postoperative endophthalmitis. Br J Ophthalmol 1997; 81: 1006-1015.

29 Mandelbaum S, Forster K, Gelender H, Culbertson W. Late onset endophthalmitis associated with filtering blebs. Ophthalmology 1985; 92: 964-972.

30 Johnson MW, Doft BH, Kelsey SF, Barza M, Wilson LA, Barr $\mathrm{CC}$ et al. The endophthalmitis vitrectomy study. Relationship between clinical presentation and microbiological spectrum. Ophthalmology 1997; 104: 261-272. 